\title{
e-Phaïstos
}

e-Phaïstos

Revue d'histoire des techniques / Journal of the history

of technology

IV-1 | 2015

Les arts de guerre et de grâce (XIVe-XVIIle siècles)

\section{Créer le multiple : la Réunion des fabricants de} bronze (1839-1870)

Réunion des fabricants de bronze: the Multiple's Creation (1839-1870)

\section{Élodie Voillot}

\section{(2) OpenEdition}

Journals

Édition électronique

URL : http://journals.openedition.org/ephaistos/838

DOI : 10.4000/ephaistos.838

ISSN : 2552-0741

Éditeur

IHMC - Institut d'histoire moderne et contemporaine (UMR 8066)

Édition imprimée

Date de publication : 1 avril 2015

Pagination : 111-116

ISSN : 2262-7340

\section{Référence électronique}

Élodie Voillot, «Créer le multiple : la Réunion des fabricants de bronze (1839-1870)», e-Phaïstos [En ligne], IV-1 | 2015, mis en ligne le 22 novembre 2016, consulté le 15 septembre 2020. URL : http:// journals.openedition.org/ephaistos/838

Ce document a été généré automatiquement le 15 septembre 2020.

Tous droits réservés 


\title{
Créer le multiple : la Réunion des fabricants de bronze (1839-1870)
}

Réunion des fabricants de bronze: the Multiple’s Creation (1839-1870)

\author{
Élodie Voillot
}

\section{NOTE DE L'ÉDITEUR}

Nous n'avons pas obtenu l'autorisation de publier ce document en ligne.

\section{RÉSUMÉS}

Au début du XIXe siècle, plusieurs fabricants de bronzes parisiens décident de s'allier et de fonder une société : la Réunion des fabricants de bronze. Héritière de l'ancienne corporation des fondeurs, la Réunion propose un nouveau modèle de groupement professionnel pour accompagner les transformations contemporaines et le développement sans précédent que connaît l'industrie du bronze entre 1839 et 1870 . Portées par des innovations techniques, telle que l'invention de la machine à réduire, de nouvelles questions commerciales, juridiques et esthétiques, se posent alors aux acteurs de cette industrie. Comment promouvoir les productions parisiennes sur un marché de plus en plus international ? Comment lutter activement contre la contrefaçon des modèles qui sévit ? Comment faire reconnaître la valeur esthétique d'ouvrages relevant tant de l'art que l'industrie ? Dans une société marquée par la multiplication des images et des objets, à un moment où le souci de la démocratisation de l'art devient un enjeu politique, l'édition de sculptures participe à la constitution d'une culture visuelle tout en posant les prémisses d'une conception du multiple comme œuvre d'art. À travers l'étude de la Réunion, de son fonctionnement et, plus spécifiquement, de son rôle de tribunal arbitral, l'enjeu de cette 
thèse est de comprendre comment les actions pour la reconnaissance juridique du caractère artistique de productions industrielles s'articulent avec une conception spécifique de la reproduction comme création.

In the early nineteenth century, several Parisians bronze's manufacturers decided to join their forces and based a society: the Bronze Manufacturers Union. Heir to the old guild founders, the Union offers a new model of professional association to accompany the contemporary transformations and the important development of the bronze industry between 1839 and 1870 . Supported by technological innovations such as the invention of the sculptures' reducing machine, new commercial, juridical and aesthetical issues arise to industry protagonists. How to promote the Parisian productions in an internationalized market? How efficiently fight against models counterfeit? How to recognize the aesthetic value of works involved in both art and industry? When democratization of art becomes a political issue, sculptures edition takes part of the creation of a visual culture and establishes principles of multiple in art. Through the study of the Union organization and, more specifically, its role of arbitral court, the goal of this thesis is to understand how the actions for the legal recognition of industrial productions as artworks is relate to the idea that reproduction could be a creation.

\section{INDEX}

Mots-clés : histoire des techniques, bronze, sculpture, art industriel

Thèmes : Positions de thèse

Keywords : history of technology, bronze, sculpture, industrial art 